\title{
$>\operatorname{ta}_{\mathfrak{a}}$
}

\section{SOVEREIGNTY AND BIOSECURITY}

CAN WE PREVENT IUS FROM DISAPPEARING INTO DOMINIUM?

by Paul Tyson 


\title{
méta Working Papers
}

\author{
Editor: Dr Sotiris Mitralexis \\ Assistant Editor: Kostas Raptis
}

\author{
Advisory Committee \\ Dr Antara Haldar, University of Cambridge \\ Dr Kostas Kanellopoulos, University of Crete \\ Dr Athina Karatzogianni, University of Leicester
}

Dr Vasilis Kostakis, Tallinn University of Technology \& Harvard University

Dr Lyndsey Stonebridge, University of Birmingham

Dr Nicolas Theocarakis, University of Athens

Dr Paul Tyson, University of Queensland

Dr Yanis Varoufakis, University of Athens

Dr Sissy Velissariou, University of Athens

Dr Mari Velonaki, University of New South Wales

The Centre for Postcapitalist Civilisation's working papers series, méta Working Papers, publishes peer-reviewed interdisciplinary research that explicitly or implicitly explores aspects of our liminal times, of our transition towards postcapitalist futures - be they dystopian or utopian, or anything in between. We are particularly interested in the exposure of academic works-in-progress to an audience of postcapitalism-oriented thinkers.

méta Working Papers welcomes solicited and unsolicited papers in English, Greek, or preferably both, on aspects of the nascent postcapitalist era and follows a singleblind peer review process. The Papers are on-line open-access publications under the Creative Commons CC BY-NC-ND license. An indicative word count would be around 3.500-7.000 words. Our non-binding suggestion for references is the Chicago Style system, either notes+bibliography or author-date. Submissions must include an abstract. Authors must include a biographical note of 60-100 words. The editorial team maintains final discretion over publication of all content. Publication does not entail an endorsement of mźta Working Papers' contents, which reflect the views only of the authors, and méta cannot be held responsible for any use which may be made of the information contained therein.

Correspondence and submission: postcapitalism.centre@gmail.com, cc'ing s.mitralexis@metacpc.org, with 'méta Working Papers Submission' on the subject line. 


\title{
Sovereignty and Biosecurity: \\ Can we prevent ius from disappearing into dominium?
}

Paul Tyson

\begin{abstract}
Drawing on Milbank and Agamben, a politico-juridical anthropology matrix can be drawn describing the relations between ius and bios (justice and political life) on the one hand and dominium and zoe (private power and 'bare life') on the other hand. Mapping movements in the basic configurations of this matrix over the long sweep of Western cultural history enable us to see where we are currently situated in relation to the nexus between politico-juridical authority (sovereignty) and the emergency use of executive State powers in the context of biosecurity. The argument presented is that pre- $19^{\text {th }}$ century understandings of ius and bios presupposed transcendent categories of Justice and the Common Good that were not naturalistically defined. The very recent idea of a purely naturalistic naturalism has made distinctions between bios and zoe un-locatable and civic ius is now disappearing into a strangely 'private' total power (dominium) over the bodies of citizens, as exercised by the State. The very meaning of politico-juridical authority and the sovereignty of the State is undergoing radical change when viewed from a long perspective. This paper suggests that the ancient distinction between power and authority is becoming meaningless, and that this loss erodes the ideas of justice and political life in the Western tradition. Early modern capitalism still retained at least the theory of a Providential moral order, but since the late $19^{\text {th }}$ century, morality has become fully naturalized and secularized, such that what moral categories Classical economics had have been radically instrumentalized since. In the postcapitalist neoliberal world order, no high horizon of just power -no spiritual conception of sovereignty- remains. The paper argues that the reduction of authority to power, which flows from the absence of any traditional conception of sovereignty, is happening with particular ease in Australia, and that in Australia it is only the Indigenous attempt to have their prior sovereignty -as a spiritual reality- recognized that is pushing back against the collapse of political authority into mere executive power.
\end{abstract}

Dr Paul Tyson is an interdisciplinary scholar working across sociology, theology and philosophy. He is an honorary senior fellow at the Institute for Advanced Studies in the Humanities at the University of Queensland, Australia, and a member of méta's Advisory Board. 


\section{Context}

We live in post-capitalist times. The political economist Yanis Varoufakis makes the point that the competitive market liberalism advocated by Classical economists as a key feature of what Marx describes as capitalism, no longer exists ${ }^{1}$ (and perhaps it never existed). ${ }^{2}$ We now live in a context that Varoufakis calls techno-feudalism. ${ }^{3}$ Here, the ideas of both free market economics and liberal democracy seem strangely disconnected from how we are actually governed. Who can really believe that it is nation states and voting citizens who are the locus of political and economic decision making in our times? (Recall the Greek referendum of 2015.) As Foucault has pointed out, there are many centres of power, ${ }^{4}$ but today, stateless financial actors tend to pull the strings of nation states, ${ }^{5}$ and that string pulling constrains

\footnotetext{
${ }^{1}$ Yanis Varoufakis et al., Is Capitalism Broken?, London: Oneworld Publication, 2020.

${ }^{2}$ Looking at the manner in which the East India company operated in the era of Adam Smith, the case can be argued that the supposedly invisible hand of free trade has never existed, and the first aim of market economics in the high mercantile age of British global influence was, from the outset, a monopolistic control of commercial and trading power, rather than a fair and self-regulating system of free trade. See Shashi Tharoor, Inglorious Empire: What the British did to India, London: Penguin, 2018.

${ }^{3}$ Yanis Varoufakis, "Techno-Feudalism is Taking Over" Project Syndicate Op-ed, 28 June 2021, https://www.yanisvaroufakis.eu/2021/07/05/techno-feudalism-is-taking-over-project-syndicate-op-ed/

${ }^{4}$ For an excellent concise summary of Foucault's insights about the supposed power of the modern nation state in our times, see Andrew Willard Jones, "The Priority of Peace and the Problem of Power", Communio, 48, no. 2 (Summer 2021): 307-310.

${ }^{5}$ For few examples of useful texts in this area, see: Satyajit Das, Extreme Money. Masters of the Universe and the Cult of Risk, USA: FT Press, 2011; Susan George, Shadow
} 
what citizens can choose in a manner that often makes democratic politics little more than a rather unbelievable exercise in collective make-believe. In reality, we live in a post-capitalist and functionally post-democratic world.

The nation state, however, is not powerless. But it is increasingly becoming an economically responsive (rather than active) and nonpolitical power, and is relation to its own citizens is increasingly one of executive control with the army, intelligence agencies and police, under emergency powers provisions, playing an ever more prominent role. Biosecurity, in our COVID times, is a sphere in which the power of the nation state is very clearly felt. But increasingly, it seems hard to distinguish valid political authority from mere executive force. This is the context in which this paper explores the concept of political sovereignty.

\section{Introduction}

This essay argues that a serious underlying crisis of sovereignty is uncovered in the Australian government's current pursuit of biosecurity. The argument runs on two parallel tracks. One track seeks to describe the origins and nature of our present crisis of sovereignty. The other track explores the new role that emergency powers now play in incrementally replacing sovereignty with executive State power. This is going to be a complex argument because distinguishing between

Sovereigns. How Global Corporations are Seizing Power, Cambridge: Polity, 2015; Nicholas Shaxson, Treasure Islands. Tax havens and the Men who Stole the World, London: Vintage, 2012; Brandon L. Garrett, Too Big to Jail. How Prosecutors Compromised with Corporations, Cambridge MA: Harvard University Press, 2014. 
sovereignty as the grounds of political and legal authority, and sheer executive, procedural and administrative State power, is no longer obviously correct. I will advocate the recovery of sovereignty as the best solution to our present crisis, via restoring the distinction between power and authority. To do this we will need to re-introduce metaphysics and theology into our naturalism and our politics. Indigenous Australia, against considerable opposition, is leading the way in this endeavour.

Traditionally, sovereignty concerns just and legitimately authorized ruling power. That is, sovereignty entails the notion of a subordinate relationship of enforcement power to just authority. I will argue that the transcendent idea of Justice and the divine authorization of valid governing power embedded in our long Western traditions of law and politics have become increasingly meaningless over the past two centuries. This leaves us unsure about the difference between power and authority. Specifically, the influence of a strictly non-theological naturalism, particularly since the late $19^{\text {th }}$ century, has eroded the traditional sharp distinction between private and natural power (dominium), and divinely overshadowed justice and governing authority (ius). The loss of a theological distinction between the natural on the one hand, and the politico-juridical on the other hand, has confused dominium and ius, disabling the ancient category delineations that historically defined sovereignty. That is, ius is disappearing into dominium, and dominium is now being increasingly exercised by the State over the passive bodies of its subjects.

The second track seeks to unpack how the covid pandemic uncovers this crisis of sovereignty. In his analysis of the pandemic Giorgio 
Agamben explores the manner in which "bare life" - merely economic, consumer, and physical life - has now largely replaced any high conception of politico-juridical anthropology. That is, simply being alive and having our physical needs and desires met, has replaced any intrinsically dignified and spiritual understanding of the meaning of human life. In this context any collective threat to our physical and economic wellbeing means that we now expect the State to override normal law and normal political processes, to simply keep us safe and financially secure. This illustrates a crisis of sovereignty because our "bare life" non-theological naturalism reduces all concepts of authority to power, abolishing any metaphysical distinction between private power and public authority. Indeed, under emergency conditions we are made safe by suspending normal law such that our bodies are treated as the private property of the State over which it has a total right of control. This underlying crisis of sovereignty is expressed in ever more information invasive and public movement controlling emergency powers.

The above argument is not intended as a negation of the valid use of emergency powers by the State. Such executive powers exercised in the interests of public safety have a long tradition of use, and this is often a good thing. But prior to the rise of non-theological naturalism, emergency provisions existed within a context of transcendent Justice and divine authority that we can no longer assume. Whether emergency powers are simply used for emergencies, or are subtly becoming the normative mode of governance, will be explored in this paper. This paper will try and ascertain whether our crisis of sovereignty means

\footnotetext{
${ }^{6}$ Giorgio Agamben, Where Are We Now? London: Eris, 2021, 38-41.
} 
that it is now simply 'natural' for ever-expanding invasive government powers to incrementally replace transcendent law, replace political accountability, and replace any high category of ruling authority. This paper will ask if the very meaning of justice and politics is being unrecognizably transformed in our times such that the very idea of sovereignty in the Western tradition is becoming obsolete, to our devastating loss.

Six key terms are crucial in the argument that follows.

\section{Key terms}

\subsection{Latin dominium and ius}

The first two terms are drawn from Roman law: dominium, meaning private power, and ius, meaning public justice. These terms concern the differences between the proper sphere of private power over oneself and one's private property (dominium), and the proper sphere of public justice within the civic arena (ius). ${ }^{7}$

\subsection{Greek zoe and bios}

The second two terms are drawn from Classical Greek philosophy: bios and zoe. ${ }^{8}$ Bios is about the purposeful and distinctive ways that different beings live, and is, as with ius, a civic and political concept when

${ }^{7}$ See John Milbank, Theology and Social Theory, $2^{\text {nd }}$ ed., Oxford: Blackwell, 2006, 918.

${ }^{8}$ See Giorgio Agamben, Homo Sacer, Stanford: Stanford University Press, 1998, 111. 
applied to people. ${ }^{9}$ Zoe simply means 'life', and this is not a political term in Greek thinking. ${ }^{10}$

\subsection{Four Naturalisms}

The meaning of the idea of 'naturalism' undergoes at least four radical changes in the large sweep of the Western history of ideas:

1. In Classical Antiquity nature was the domain of pagan gods as regards elemental powers, as well as the pre-political and often both violent and passionate domain of blood relations as regards natural human affairs. ${ }^{11}$

\footnotetext{
${ }^{9}$ In Classical Greek categories 'biology' would be the study of what makes different forms of life distinctive; that is the distinctive forms of life are studied in biology. In contrast 'zoology' would be the study of life itself, in any form. The modern nomenclature is almost the other way around. We now think of biology as the study of all living things - plants, microbes, animals - and zoology as a sub-branch of biology, in that it is the study of animals only. The modern mind has no conception of 'form' in Classical categories, where 'form' - meaning 'soul', 'intelligible essence' is a purposive, qualitative and eternal category. Because the Classical conception of 'form' is no longer part of our understanding of natural philosophy, we see no conceptual difference between biology and zoology, we only see a distinction of categories with zoology being a sub-branch of biology.

${ }^{10}$ Agamben explains that even though Aristotle defines humans as political animals (politikon zoon), the use of zoon (a derivative of zoe) here is qualified by politikon explicitly distinguishing the human life-form from life-forms appropriate to non-human animals. Humans are the only animals that can be political, as they are capable of using speech and reason to govern themselves. So humans, zoologically, are animals just like any other animal, excepting that (biologically) they can live politically. See Agamben, Homo Sacer, 2-3.

${ }^{11}$ Walter Burkert, Savage Energies, Chicago: University of Chicago Press, 2001; Werner Jaeger, The Theology of the Early Greek Philosophers, Eugene OR: Wipf \& Stock,
} 
2. In Medieval Christendom the Western idea of the natural was embedded in and overshadowed by the divine Creator. ${ }^{12}$

3. By Early Modernity, Western Christian naturalism typically isolated the supernatural from the natural, making the natural theologically 'self-standing' in an entirely new way. This new 'purely natural' (natura pura) naturalism was often characterized by a firmly instrumental approach to nature, as an expression of Adam's mandate to subdue and rule the earth. ${ }^{13}$

4. Late Modern non-theological naturalism rises to prominence in the late Victorian era. This is a fully secularized conception of 'pure nature', integral with the professionalization and de-clericizing of 'science' and the firm separation of 'science' from 'religion'. ${ }^{14}$

2003 [1936]; Pliny the Elder, Natural History, London: Penguin, 1991; Chanon Ross, Gifts Glittering and Poisoned, Eugene OR: Cascade, 2014.

${ }^{12}$ Henri de Lubac, The Mystery of the Supernatural, New York: Herder \& Herder, 2018 [1965]; Josef Pieper, Guide to Thomas Aquinas, San Francisco, Ignatius Press 1991 [1962]; C.S. Lewis, The Discarded Image, Cambridge: Cambridge University Press, 1964; Robert Bartlett, The Natural and the Supernatural in the Middle Ages, Cambridge: Cambridge University Press, 2008.

${ }^{13}$ John Henry, Knowledge is Power, London: Icon Books, 2002; Louis Dupré, Passage to Modernity, New Haven: Yale University Press, 1993; Reijer Hooykaas, Religion and the Rise of Modern Science, Vancouver: Regent College Publishing, 2000; Keith Thomas, Religion and the Decline of Magic, London: Penguin, 1971.

${ }^{14}$ Peter Harrison, The Territories of Science and Religion, Chicago: The University of Chicago Press, 2015; Stewart Goetz \& Charles Taliaferro, Naturalism, Grand Rapids MI: Eerdmans, 2008. 


\subsection{Emergency Powers}

The meaning of 'emergency powers' concerns our government's use of special executive powers that override normal law. This dynamic assumes that in an emergency there is a valid relationship between executive power that overrides normal law, and the sovereign authority of the state. I will look at this relationship by appropriating aspects of Carl Schmitt's thought. Schmitt's notion of how 'the state of exception' defines political sovereignty is - I shall argue - parodied by the contemporary understanding of 'the state of emergency' produced by the global covid pandemic.

To Schmitt the "state of exception" defines political sovereignty. ${ }^{15}$ When there is no existing law or precedent suitable for meeting a novel crisis, Schmitt says, we can discern where sovereignty lies because genuine political authority will decide what to do in unprecedented times to preserve the justice and political integrity of the state. Yet, in Schmitt's analysis, what characterizes $20^{\text {th }}$ and $21^{\text {st }}$ century Western liberal democratic politics is the striking absence of political authority, and the striking absence of political decision making. Schmitt is a jurist, not a theologian, so whilst he is aware that the theological undergirding of Western categories of sovereignty have been secularized, ${ }^{16}$ possibly to the point of disintegration, he does not look for a theological solution to this problem. But the crisis within the metaphysical categories of political sovereignty that the secularization of theological concepts in law and politics produces is his central

\footnotetext{
${ }^{15}$ Carl Schmitt, Political Theology, Chicago: University of Chicago Press, 2005 [1922, 1934], 5-15.

${ }^{16}$ Schmitt, Political Theology, 36: "All significant concepts of the modern theory of the state are secularized theological concepts..."
} 
interest. In this context Schmitt has a profound anxiety that the unfettered exercise of executive, financial and administrative power acts as an inadequate substitute for sovereignty, precisely because there is no exercise of genuinely political decision making and authority. Thus 'emergency powers' in our day parody Schmitt's conception of the genuinely political 'state of exception' but our emergencies seem to have the aim of not simply exercising sovereignty, but of creating it. Yet the very meaning of political authority itself is transformed in this parody as the executive power thus deployed is a dominium power (a lordship) over human zoe, and is not only non-political, but anti-political. ${ }^{17}$

\section{The Ius-Dominium-Bios-Zoe matrix, and the shifting notion of 'naturalism'}

The ius-dominium-bios-zoe matrix of inter-relations between the natural and the political, and power and justice, have undergone many transformations in the long traditions of Western civilization. Let us now explore more closely four basic configurations that loosely map onto four massive transitions in law and politics, which I will call

\footnotetext{
${ }^{17}$ See: Yanis Varoufakis, And the Weak Suffer What They Must?, New York: Avalon, 2016; Yanis Varoufakis, Adults in the Room, New York: Farrar, Straus and Giroux, 2018. These two books describe the manner in which the Greek referendum of 2015 was entirely overridden by both the Greek Parliament and powerful financial and bureaucratic forces in and beyond the Eurozone. It is frighteningly possible that liberal democratic politics is now only treated as 'sovereign' if it acts in accordance with non-political 'rational' and 'realist' power interests. That is, it is frighteningly possible that there is no real political authority within liberal democratic politics, but that the form of the sovereign political will of the people is just a procedural fig-leaf covering the naked sectional interests of non-political mere power.
} 
the Classical, the Medieval, the Early Modern, and the Late Modern configurations. It is largely different understandings of what the natural and the divine are, and how the private and the natural is delineated from the public and the transcendent that shapes the shifting dynamics of justice and sovereignty in the West's long traditions of governance and law. By noting carefully how pre-contemporary Western configurations work, our own configuration will become more visible to us.

\subsection{The Classical Ius-Dominium-Bios-Zoe configuration}

To quickly re-cap, dominium is, as Milbank puts it, unrestricted lordship over what lies within one's private power in Classical Roman law. ${ }^{18}$ Ius refers to justice in Roman public law; the domain of ius is the law of citizens and the governance of the polity. Classical Greek zoe and bios map onto the distinction between the private and the political. ${ }^{19}$ Zoe concerns the basic physical realities of life, which are pre-political. Bios concerns distinctly human life, how we live in a properly human manner with each other in a just and political community.

The distinction between the public and political bios, and the private and non-political zoe is juridically crucial in Classical antiquity. For the public citizen, bios is life as defined by the political nature and purposes of civic life. Zoe, in contrast to bios, is life in the private households and anywhere else outside the proper domain of political life. Bios as defined by the appropriate modes of political life - the bios politikos - is overshadowed by the transcendent and theological

\footnotetext{
${ }^{18}$ Milbank, Theology and Social Theory, 13.

${ }^{19}$ Agamben, Homo Sacer, 1.
} 
horizon of the common good. Bios is formed life - life formed towards certain distinctly human and metaphysically defined ends - rather than the mere physical necessities and creature comforts of natural life $(z o e) .^{20}$

Three features of the bios politikos describe its essence: (1) it is defined by speech; (2) it is situated in the context of the high metaphysical and moral horizons of the common good, and; (3) it is ultimately theologically defined by ineffable and divine Justice. Bios is exactly not governed by mute and brute animal force. That is, what we now think of as "political realism" is a non bios politikos category of brute power that would be unrecognizable as political to the Classical mind. In other words, what may occur outside of the proper sphere of the political - be it the private domain of the household, be it any lawless arena of mere force beyond the sphere of any unified politico-legal authority, or be it in the technological domain of any purely necessary relation of designing will to instrumental force to controlled outcome - is not a bios politikos matter. Brute animal force, manipulative instrumental power, amoral cunning, or irresistibly imposed external will, is simply not politics. In contrast, that which occurs within the ius of civil law, and of political life, is governed by speech, by rights and responsibilities, and by indeterminate (genuinely free) agreement. Ius is

\footnotetext{
${ }^{20}$ In modern categories, we might distinguish 'consumer anthropology' from 'political anthropology'. Consumer anthropology is defined by zoe, where the end of our animal natures is the mere satiation of physical needs, physical desires, and the amoral will to power of individuals. In contrast, political anthropology is defined by a distinctive bios where the ends of human flourishing are explicitly moral, corporate and metaphysical; such as justice, the common good, and proper civic piety towards the high source of transcendent value and meaning as partially and imperfectly expressed in the polis.
} 
a function of the divine authority that defines the nature of rulership that is appropriate to the human realm of the bios politikos. Political and juridical authority thus denies mere dominium, mere techne, mere potestas, any determinate power in both governance and court. The means of power, then, must serve the end of justice under the rule of any genuinely political and juridical authority. In the bios politikos this relationship is never the other way around such that justice and authority become the mere tools of power.

\subsubsection{Classical Pagan naturalism}

A significant feature of Classical Antiquity that needs to be grasped is that the private domain of zoe, though not a political domain, was a sacred domain in its own categories. Zoe was not naturalistic in the non-theological categories we associate with the word 'naturalism' today.

In Classical Antiquity nature (physis) was largely seen as the domain of the gods as regards elemental powers. This domain was integral with the sub-political affairs of blood relations in the home, our animal necessities (shelter, food, procreation), natural aggression, and mortality. ${ }^{21}$ Due to a very spiritual conception of High Deity, the Classical world largely assumed a low theological naturalism. ${ }^{22}$

\footnotetext{
${ }^{21}$ See Simone Weil's profound analysis of the daemonically integral honour culture of ancient Greek warriors, along with its fatalism as regards violent force and mortal combat. Simone Weil and Rachel Bespaloff, War and the Illiad, New York: New York Review of Books, 2005.

${ }^{22}$ In this context a 'high' natural theology entails the intimate dependence of physical creation on God, and 'low' natural theology entails a somewhat distant relationship between nature and God.
} 
In contrast with Hebraic and Christian theologies of nature, Pagan Classical thinking assumed that the physical cosmos below the orbit of the moon was not created by God. According to Plato's theorizing, the visible cosmos was built by a daemonic being of great power called the Demiurge (Craftsman). ${ }^{23}$ God was too spiritual, too lofty to get directly involved in the imperfect and temporal material realm. Aristotle's God - thought the First Mover of all reality - is a purely intellective ultimate entity, described by Aristotle as "thought thinking itself." ${ }^{24}$ The physical world, then, is crafted, enamoured, and animated by semi-divine daemonic entities - nature's gods - whose amoral, immoral and irrational tendencies should in no manner be ascribed to High Deity. ${ }^{25}$ To this outlook, natural and physical beings like us - at least at the level of zoe - are largely governed by daemonic powers that are integral with our animal instincts. Zoe is thus a sacred domain, but it is beneath and outside of civic law.

To the Pagan Classical mind, the spiritual energies of nature we dread are just as natural as the spiritual energies of nature we desire. To the Pagan, the instinctive animal drives we all experience - both for life and kindness, and for death and cruelty - are equally within

\footnotetext{
${ }^{23}$ Plato, Timaeus, 28a6, 40c2, 41a7, 69c3.

${ }^{24}$ Aristotle, Metaphysics, $1072 \mathrm{~b} 20$.

${ }^{25}$ Plato in particular rejects the impiety of ascribing mythic accounts of the gods to God. On Plato's theology, see Walter Burkert, Greek Religion, Oxford: Blackwell, 1985, 305-338. The brilliant classicists E.R. Dodds is very helpful in understanding Classical Greek concepts of the daemonic and the differences and commonalities between Pagan and Christian understandings of reality in late Classical times. See E.R. Dodds, The Greeks and the Irrational, Chicago: University of Chicago Press, 1951; E.R. Dodds, Pagan and Christian in an Age of Anxiety, Cambridge: Cambridge University Press, 1965.
} 
the domain of the daemonic natural powers to which we are subject as mortal animals.

However, purely natural and daemonic matters are decidedly subpolitical. Further, it is only in the political domain that the high dignity of Man - a rational and speech endowed animal - is distinctively displayed. Hence zoe, along with the daemonic, is not permitted entry to the civic and political realm. The civic domain is overshadowed by high theology - divine justice and the highest good - rather than the low theology of the daemonically natural.

\subsubsection{The bios politikos of the Classical configuration}

In sum, dominium was held explicitly distinct from ius in the very structure of Classical political philosophy. The distinction between private and non-political dominium and civic ius thus distinguished mere force from divinely authorized justice. This is a distinction between civil, political, juridical and law-governed forms of life (bios politikos) and private, 'natural', power and force-governed, merely animal life (zoe).

The Classical distinction between zoe-dominium and bios-ius remains largely intact during the Greco-Roman era, but in significant regards disintegrates with the completion of the codification of Roman law by Emperor Justinian I in the East in the $6^{\text {th }}$ century, and the demise of the Western Classical civilization in the $5^{\text {th }}$ and $6^{\text {th }}$ centuries. 


\subsection{The Medieval Ius-Dominium-Bios-Zoe configuration}

After a period of imperial and civilizational collapse, and of intensive missionary activity from Celtic monks, ${ }^{26}$ Western Europe emerged from the disintegration of the Classical Greco-Roman world. By the $11^{\text {th }}$ century, the dynamic civilization of medieval Christendom had come to life. The Roman Catholic Church was the only institution to survive from the Classical era into the Medieval, and it came to assume a somewhat Imperial mantle, though without being simply a political and military power.

Significant transitions occurred from Classical times as regards: authority and morality in the private domain; an understanding of nature; and, the relation of the Church to civil authority. The Classical matrix was re-drawn.

Nature was now no longer understood in pagan terms, but was understood as the good creation of God, and yet also fallen. Natural deities of amoral or immoral disposition were no longer openly worshipped. The domain of the home was still outside of the civic domain, but not outside of the authority of the Church. Thus dominium was no longer a realm of absolute patriarchal power (patria potestas). Sin was seen as a problem affecting all human spheres, and the domus was Christianised such that sexual conduct and relations of power within families were not simply matters of private dominium and natural or pagan zoe any more. ${ }^{27}$ Yet the authority of the Church - though integral with all aspects of medieval life - remained largely below and

\footnotetext{
${ }^{26}$ Thomas Cahill, How the Irish Saved Civilization, New York: Random House, 1996. ${ }^{27}$ Interestingly, we seem to be trying to return to a more Classical view of sexuality since the 1960s.
} 
above civic and political authority. Christendom, then, integrates dominium, ius, bios and zoe in a single system of authority, overseen by the Roman Catholic Church. Yet ruling authority in matters of civic and political power was delegated to emperors and kings who derived their authority to judge and rule from the Church, and ultimately from God. During this era, it was the Pope or his representative who crowned Christian sovereigns.

\subsubsection{Medieval Christian Naturalism}

The most obvious difference between Pagan and Christian naturalisms concerns the daemonic. To the Pagan, the daemonic contains no necessary connotation of evil or impiety. It is only in the Christian era that the 'demonic' becomes seen as the domain of evil, aligned with Diabolos - the Devil - in rebellious antipathy towards God. This is because the Christian God is the Hebrew God, who is the creator of heaven and earth, and the creator of man. That is, Christianity entails a 'high' theological naturalism, where nature is God's creation, the natural world is God's intimate concern, and where the physical cosmos itself has its on-going being because of the continuous creative energies of God. ${ }^{28}$ Natural evil - then - is exogenous to the Christian; here 'natural evil' is not (theologically speaking) natural. ${ }^{29}$ The dark powers of nature are now thought of as in rebellion against God. To

\footnotetext{
${ }^{28}$ The traditional Christian theology of creation is not well understood, even (perhaps particularly) by modern Christians. See Simon Oliver, Creation: A Guide for the Perplexed, London: T\&T Clark, 2017.

${ }^{29}$ That is, 'fallen nature' is unnatural when viewed from the perspective of its original unfallen goodness (Genesis 1: 31); nature itself has be "subjected to futility" (Romans $8: 20$ ) by the fall.
} 
the Christian, evil, sickness, and death exists because of a cosmic fall that effects all physical reality, which God is in the process of redemptively undoing. Natural violence is no longer thought of as simply natural, but as fallen.

Hence, in Medieval Christendom, the domain of natural life, of family life, of sexual morality, and the religious equality between men and women, ${ }^{30}$ transforms the private domain and brings it under the authority of the Church. ${ }^{31}$ Zoe and the domus (home) are still outside of civil law, but they are now under the authority of the church. The unbridled power of the Classical patriarch in his home is thus diminished.

After the rise of the $13^{\text {th }}$ century Aristotelian-Aquinan synthesis of natural philosophy with Christian theology, the Western understanding of nature was fully intellectually embedded in and overshadowed by the divine Creator. This radically impacted the manner in which a Church governed zoe - beneath the level of civic authority - functioned. In medieval Christendom there was also a close relationship between the high spiritual authority of the Church - above civic power - and the proper dignity of the bios domain of civil law and political

\footnotetext{
${ }^{30}$ Whilst Christian marriage entails role differences between men and women, with the Man still in a position of ruling the Woman, the model of the husband is now Christ who lays down his life for Hs bride (Ephesians 5:21-33) and, before God, "there is neither male nor female; for you are all one in Christ Jesus." (Galatians 3:28)

${ }^{31}$ Notably the patronage culture of indebted obligation, so brilliantly described by Marcel Mauss (The Gift, London: Norton, 1990) which was integral with systemic power inequalities in the Classical world is radically undermined by the Lord's Prayer, the Sermon on the Mount and the priority of Christian love (agape) over honour.
} 
power. The Church was required to authorize and legitimate courts and governments.

\subsubsection{A deeply integrated worldview}

To Aquinas, nature participated in intelligible and moral realities gifted to them by God, such that all natural things tend towards natural goods. The natural thus participates (sacramentally) in the supernatural, and must so participate in order to be fully natural. Here, there is no 'pure nature', if by purity we mean any natural thing as selfstandingly autonomous from the supernatural. Thus, Aquinas maintains that nature herself - as divinely enlivened and intelligibly meaningful - is not rule governed in an inertly passive and merely determinate manner. Rather, nature has virtue-defined tendencies towards the good, which are ultimately doxologically situated. Nor is nature a machine; nature is not our artefact. ${ }^{32}$ Here, the living integrity of nature herself is discrete from our knowledge constructions of nature. The Modern way of thinking about nature as a set of fixed and determinate laws over which we can have full knowledge and control, was

\footnotetext{
${ }^{32}$ The famous Classical and Medieval turn of phrase machina mundi (the machine of this world) refers to the regular motions of nature and the 'mechanical' understanding of Aristotelian celestial motion. The world might be, in one sense, God's machine in the Middle Ages, but it was certainly not our machine. That is, in the Middle Ages all natural beings are gifted with their own purposes by God, which is the central difference between a living being and a tool or machine that we construct, the purposes of which are given to it by us. In the Modern sense, a 'mechanical' conception of natural laws governing simply material objects our knowledge and technology can master and re-direct towards our own purposes, is foreign to the Medieval mind. The Medieval world view is one of sympathetic internal animate resonances rather than external and instrumental 'mechanical' causation.
} 
foreign to the Medieval mind. To Aquinas there is a certain freedom and doxological openness to nature, and she exists as God's creation before she exists as our domain of power and use. There is also natural justice and natural claims to divinely-given authority in all systems of human law, such that the mere subjugation and dispossession of First Peoples by superior force would be a violation of natural justice and natural sovereignty. ${ }^{33}$ Also, in Aquinas' outlook, the Church is the first domus (household) of the Christian and of Christendom, and political and legal life is embedded in and upheld by the redemptive vision, the moral virtue and the divinely authorizing life of the Church. Of course sin and the fallen 'natural' tendency towards the frustration of creation's original goodness means that it is now necessary for political authority, as subject to ecclesial authority, to wield force, and war also is a function of human sin. But - at least within and between the principalities of Christendom ${ }^{34}$ - power is never a dominium of externally focused force as in imperial conquering Rome, where might makes right. ${ }^{35}$ Aquinas' integrated outlook where nature below the political and the church above the political are integrated into the one form of life - Christendom - holds that zoe is a gift of God that finally still belongs to God, and the bios is overshadowed by God giving it a grounds

\footnotetext{
${ }^{33}$ Aquinas lives before the infamous Bulls of Donation in 1493 and 1494.

${ }^{34}$ Machiavelli's realpolitik still has to present that face of goodness and uphold the illusion of authority which makes its overt deception somewhat more charming than the brute and undisguised instrumentalism of the realpolitik of our times. ${ }^{35}$ Augustine in The City of God argues that the first object of love in the City of Man is self-glory. This is the idolatrous principle ordering first private power, and corrupting public power in pagan Roman society, and it is inherently egotistic, agonistic and violent. In contrast, the love of God and of neighbour as oneself is the first doxological principle of the City of God, and this is inherently harmonious and peace-loving.
} 
of authority that transcends mere human constructivism. Dominium in the private and extra-political contexts cannot, then, be defined by mere force. Likewise ius is never its own final ground; political authority is a humanly mediated and imperfectly realized divine gift.

2.2.3 The nominalist and voluntarist seeds of the demise of the Medieval synthesis

Whilst both the Classical and the Medieval worlds still profoundly shape us today, the complex synthesis of Neoplatonist metaphysics, Aristotelian logical, natural and ethical sciences, and Christian theology that comes together in Aquinas, starts undergoing significant transformations from the fourteenth century that eventually lead to its breaking down in Western European contexts. ${ }^{36}$ Significant here are fourteenth century trajectories in nominalism and voluntarism.

Fourteenth century nominalism - notably put forward by William of Ockham - starts to think of all natural objects as metaphysical singularities that do not participate in super-individual essential and spiritual realities. Nature is being de-essentialized, de-spiritualized, separated from transcendent metaphysics, and is heading towards the loss of Aristotle's formal and final causation categories. That is, divinely upheld moral and essential realities, and divinely gifted natural purposes are being removed from the idea of nature. A profound shift away from the Aquinan outlook of a supernaturally saturated

\footnotetext{
${ }^{36}$ See Milbank, Theology and Social Theory; Tracey Rowland, Culture and the Thomist Tradition, London: Routledge, 2003.
} 
nature, to the polarization of the natural from the supernatural is underway.

Fourteenth century voluntarism - complexly advocated by Duns Scotus - defines the divine nature in the categories of un-restricted sovereign will. Here, God has complete ruling power and total freedom to will and act as God sees fit. Human nature is also defined by the aspiration for total sovereignty over the domain of authority given to us by God. In this manner, it becomes normative to assume that Adam, as created in the image of God, strongly desires the unrestricted freedom to rule himself and to have total power over the earth.

\subsection{The Modern Ius-Dominium-Bios-Zoe configuration}

By the $17^{\text {th }}$ century, the idea that humanity has an Adamic right to total dominion over the earth ${ }^{37}$ is combined with the rejection of Aristotle's natural causation categories of essence, quality and purpose. With this, natural objects become just material things, such that the natural is seen as entirely discrete from the supernatural. Power, and human dominium over the earth, and a more (to us) 'naturalistic' understanding of the normal dominating relations of the strong over the weak, became mainstream in Western thinking. Michel Foucault notices that the collapse of a private sense of dominium into the public conception of unbridled state and commercial power was already

\footnotetext{
${ }^{37}$ Peter Harrison, The Fall of Man and the Foundations of Science, Cambridge: Cambridge University Press, 2007.
} 
firmly in place by the dawn of the modern era. ${ }^{38}$ This is happening at the same time that the supernatural is being decisively separated from the natural. Ancient ties between the divine grounds of being and nature are being undone. Subtly, ancient ties between divine reality and ius are also being undone. The sphere of the political is being naturalized, and the concept of unbridled dominium as a central anthropic principle is being extended into trade, colonial enterprises and politics itself. These trajectories profoundly undermine Medieval theological and metaphysical categories of political justice and just judgement in law, as well as making the Classical categories of the political life and the common civic good increasingly incomprehensible. The manner in which nature itself is increasingly understood as entirely separate from divinity is at the centre of these transitions.

Milbank argues that by the time of Grotius in the early $17^{\text {th }}$ century, the Aquinan synthesis was seriously undermined. ${ }^{39}$ Significant in this undermining was a transfer of category meanings such that the man made and more fully knowable categories of human laws become imposed on nature and on power. The origins of the modern scientific notion of the laws of nature seem to actually derive from dominium concerned legalistic thinking. Milbank notices these trends at the dawn of the modern age:

1. facts (factum, 'the made') as human artefacts of knowledge are starting to define nature;

\footnotetext{
${ }^{38}$ Agamben, Homo Sacer, 3, citing the end of the first volume of Michel Foucault's The History of Sexuality. [1976]

${ }^{39}$ Milbank, Theology and Social Theory, 9-18.
} 
2. facts are thought of as providing us with a fully determinate and universal system of humanly-constructed knowledge;

3. systems of law - both natural and legal - are constructed to be as determinate, as power enhancing, and as universal in their general parameters as possible;

4. human dominium over nature becomes thought of in terms of understanding and using the laws of nature;

5. the international domain become seen as rulegoverned and also as largely defined by 'natural' power and interest.

To proceed in this way is not the fulfilment of Aquinas' Christendom thinking, but its abandonment. Nature itself is now seen as juridical and forced to comply with our determinate laws (lex), and the 'laws' of nature are seen as power-defined in much the same way as the old Roman notions of dominium and potestas saw the total right of private power. The Medieval matrix of the natural and the political was being re-drawn.

The modern configuration of dominion and ius, bios and zoe starts in earnest in the $17^{\text {th }}$ century. It is no accident that Sir Francis Bacon was both the first Queens Counsel barrister, and a key instigator of what we now call the scientific revolution. Nature and law are being pragmatically fused. Bios and zoe are being fused. Ius is beginning to be defined in terms of a modern naturalistic dominium. 


\subsection{The Late Modern Configuration}

Medieval categories of power and authority undergo significant ecclesial fragmentation and re-thinking in the Reformation of the $16^{\text {th }}$ century, but remain largely intact in Western European legal and political contexts in early modernity. Further, though disintegrating, Medieval categories remain strongly active until the late $19^{\text {th }}$ century. They become seriously diminished in A.V. Dicey's influential advocacy of English parliamentary supremacy in the late $19^{\text {th }}$ century. It is not until the $20^{\text {th }}$ century that they are firmly culturally dislodged, notably from about 1965 onwards. A massive demographic decline in Church affiliation by the post-war generation is evident from the mid-1960s in most Western democracies, other than the United States. However, the remnants of theologically-warranted medieval categories of authority and sovereignty remain active to this day in the political and legal traditions of English law and government, at the same time that modern categories have been laid over them. The transition from $\mathrm{Me}$ dieval to Modern is complex and not actually complete, to this day.

It is only in the late $19^{\text {th }}$ century that a distinctly modern conception of political authority manages to break free from Medieval categories of theologically-situated justice and authority. Liberal democratic politics as we now know it arises in concert with the naturalistic utilitarian ethics and the constructivist social contract theories of the $19^{\text {th }}$ century, raising the popular will - as expressed by representative parliament - to an entirely new category of political authority. Also in the Victorian era, scientistic and anti-theological naturalism is embraced by Thomas Huxley and his X-Club as a justification for de-clericizing and professionalizing natural philosophy, and creating the modern war between science and religion. Progressives indebted to David 
Strauss, Ludwig Feuerbach and Karl Marx moved from being fringe radicals in the 1840 s to boldly reforming scientific atheists by the turn of the $20^{\text {th }}$ century. Herbert Spencer and Bertrand Russell were certainly radical in their anti-Christian naturalistic missionary fervour, but they were entirely mainstream in their own life-times. The Early Modern ius-bios-dominium-zoe matrix is being profoundly re-drawn by the turn of the $20^{\text {th }}$ century.

In the Late Modern configuration ius becomes a cultural construction based on and needing no source of authority other than human creative genius, pragmatic persuasion, and rational scientific logic. Parliament, then, has political authority for no other reason than it procedurally represents the will of the governed. Provided the proper legislative process is followed, whatever laws parliament produces are formally just, which now equates with justice itself, as there is no substantial conception of justice which stands above human power and authority available to the Modern naturalistic mind. But here, increasingly, the distinctive forms of political life (bios) are defined - in the final analysis - only by the physical needs and animal desires of human zoe. For our anti-theological naturalism understands only zoe as objectively and physically real, and thinks of bios as a subjective cultural construction that simply masks the primal drives and necessities of zoe. By this means, zoe and bios become only fictively separate, and ius and dominium, likewise, become a naturalized unity where the reality of power is simply dominium. Here, the thin creative secretions of ius are furtively and somewhat deceptively pasted over Freud's two primal powers; death and sex..$^{40}$ In the early $20^{\text {th }}$ century, Picasso and

\footnotetext{
${ }^{40}$ Sigmund Freud, Civilization and its Discontents, London: Penguin, 2002.
} 
Stravinsky, for example, find primitive instinctive realities alone to be the real determinates of human culture and meaning.

\subsubsection{Late Modern naturalism}

By the late Victorian era, Thomas Huxley's newly professionalized and de-clericized sciences tended to presuppose a functional materialism as integral with objective knowledge. This non-theological and scientifically reductive understanding of reality largely dissolved pre$19^{\text {th }}$ century distinctions between bios and zoe. Prior to this time the distinctly political forms of public life native to the Classical, Medieval and Early Modern Western milieus had been defined by finally theological accounts of humanity, justice and authority. ${ }^{41}$ Hence, the ancient distinction between a private sphere of unwritten and natural law that is 'given', and a public sphere of divinely-authorized and yet intentionally 'made' and written civic law, becomes incoherent within the late Victorian and purely naturalistic account of reality. By the $20^{\text {th }}$ century, bios becomes increasingly defined by zoe. Cultural constructions of meaning - including law, religion, and political institutions are increasingly seen as entirely naturalistically defined. Reference to divinity and transcendent moral realities become increasingly meaningless in the theory and practice of politics and law. This produces a complex crisis in the Late Modern concept of legislative and political authority, a crisis that is yet to be resolved..$^{42}$

\footnotetext{
${ }^{41}$ See again Schmitt's historically and juridically true observation: "All significant concepts of the modern theory of the state are secularized theological concepts..." Schmitt, Political Theology, 36.

${ }^{42}$ Jonathan Horton, "Limits of Legislation as a Source of Law: An Historical and Comparative Analysis." PhD (law) Thesis, The University of Edinburgh, 2015. Dr
} 


\subsubsection{The Late Modern Crisis of Sovereignty}

The crisis of sovereignty we are discussing here concerns whether there really is any difference between force and authority, between interest and justice. The long pre-Victorian traditions of the West, going right back to Classical times, had strongly upheld the notion that sovereign and just authority was defined by such a difference.

The argument by Thrasymachus in Book I of Plato's Republic that "justice is nothing other than the advantage of the stronger" 43 is intrinsically at odds with the long traditions of Western jurisprudence and political philosophy. Indeed, the entire point of Plato's Republic is to repudiate Thrasymachus' denial of any difference between power and

Horton explains how legislative hyperactivity (the making of ever more laws at an ever faster pace) is a function of the idea of Parliament's governing authority that arises in the $17^{\text {th }}$ and $18^{\text {th }}$ centuries. Here, the submission of the people to government is thought of as requiring that Parliament procedurally represents the will of the governed. By the late $19^{\text {th }}$ century, law-making is also increasingly understood in secularized, naturalistic, and non-metaphysical terms. Law construction is seen less as an imperfect attempt to assist concrete judgements as overshadowed by transcendent Justice, and more as the very act of creating a rule governed and hence just social order. Parliament now seems to have a tendency to want to generate its ruling authority by the procedural act of making rules. This situation has a range of internal contradictions and politically and juridically paralysing effects that are only made worse by increasing the speed and range of legislative reach. In a crisis, politicians are tempted to legislate for emergency provisions that allow governments to overrule a quagmire of rules in order to meet specific novel governmental challenges. This situation indicates that there is an underlying problem in the categories of political and legal authority in our hyperactive Parliamentary norms, and this underlying problem is not presently being addressed. ${ }^{43}$ Thrasymachus explains: "justice is nothing other than the advantage of the stronger... [For] each city ... makes laws to its own advantage... and they declare that what they have made - what is to their own advantage - to be just for their subjects... Justice is... the advantage of the established rule." (Rep. 338c-e) 
justice. In this aim, Plato was clearly successful in the history of Western jurisprudence. For it is the distinction between justice and mere power, and it is the distinction between proper authority and sheer force, that defines the Western traditions of law and governance. Of course the powerful often seek to bend government and law to their own advantage, but this is understood as a miscarriage of justice, not as its essential nature in the Western traditions deeply formed by Plato and Aristotle, Roman understandings of governance and law, and Christian understandings of governance and law. But if we can no longer distinguish between physical force and metaphysical Justice, this is because we can no longer distinguish between the proper and private domain of bare life (zoe) and the public domain of political life (bios), or between 'natural' force (dominium), and the transcendently overshadowed just (ius) use of power by our government.

When the source of the authority of government and the justice of law is unclear, this defines the distinctly post $-19^{\text {th }}$ century crisis of Western liberal and democratic sovereignty that Schmitt notices. States of emergency uncover this crisis because within them the political rights and responsibilities of citizens (bios defined ius) become an obstacle to the effective executive power of the state. Worse again, in our day an emergency can easily become an opportunity to replace politics and justice (bios and ius) with executive state power (subjugating private zoe to the dominium powers of the State).

\section{Biosecurity, the crisis of sovereignty and the state of emergency}

At this point, a further discussion of Carl Schmitt is helpful. Schmitt finds that $19^{\text {th }}$ century Enlightenment-framed attempts to re- 
create political authority without a sovereign who has the metaphysical authority to make a genuinely exceptional political decision, illustrates the distinctive crisis of sovereignty for modern liberal democratic government. The problem is two-fold. Firstly, the divine warrants of mediated sovereignty are being radically displaced, leaving open the question of why ruling power needs any warrant in justice at all. Strongly anti-Christian political theorists of the Progressive $19^{\text {th }}$ and $20^{\text {th }}$ centuries saw the will to power, and violence itself, as the only genuine grounds of power, and barbaric revolutionary terror as an essential ingredient in establishing political power without divine authority. ${ }^{44}$ Secondly, in a crisis, the endless discussion and interest trading of parliament is not equipped to make a genuinely decisive political decision in order to save the state. Vesting final political authority in an office held by a real person - so Schmitt argued - enabled a state to be ruled by a genuinely political decision during a state of exception.

Briefly, Schmitt's complex relation to Weimar era German politics, his intimate appreciation of the catastrophe of World War One for Germany, and his compromised relation with the Nazi regime between 1933 and 1936 makes his work on the state of exception difficult to interpret. It seems likely he sought alliance with the Nazis in order to try and prevent the collapse of German politics into dictatorship,

\footnotetext{
${ }^{44}$ The revolutionary tradition of Robespierre's 1793-94 reign of terror was followed again in the Russian Revolution, was upheld by Stalin and was practiced in Maoist China. This is not just a Progressive ideology as Suharto and US backed Cold War regimes in South America also followed Mao's aphorism that 'political power grows out of the barrel of a gun.' For two $19^{\text {th }}$ century theorist of the anti-Christian morality of will and power see Friedrich Nietzsche, Beyond Good and Evil, New York: Dover, 1997; Arthur Schopenhauer, The World as Will and Idea, London: Orion, 1995.
} 
and failed. His anti-Semitism in the Nazi era remains deeply shocking. But whether his work was rightly or wrongly appropriated by $\mathrm{Na}$ zism, and what his final outlook on Nazism was, are not the concern of this paper. His interest in the modern crisis of sovereignty is the present focus.

In a crisis of the state, sovereignty is exercised in the making of a decisive and unprecedented political judgement that is political because it aims to save the state by preserving politics itself (the bios politikos) and upholding the authority of just rule (ius). Schmitt thought that in a genuine crisis, factional deliberation could not deliver a decisive and genuinely political outcome, but would be paralysed. For this reason, he thought that sovereign authority must finally be vested in a person rather than a system. This need not be a king, so a sovereign could emerge from within liberal democratic parliamentary government, but only if politicians were genuine leaders acting in the moral, political and metaphysical interests of the entire state, rather than servants of sectional power blocks promoting, finally, sectional interests in which they also had a vested interest. ${ }^{45}$ Of course the problem here is that the demagogue, the would-be dictator, is waiting in the wings for the exception in order to take advantage of the political paralysis of liberal democracy in crisis, and sweep aside politics itself. But the central point here is not that a crisis creates sovereignty to

\footnotetext{
${ }^{45}$ That is, Thrasymachus' understanding of law makers and political figures acting to preserve the "advantage of established rule" is too naturally at home in liberal democratic parliamentary power for Schmitt. It is better - so Schmitt seems to imply - if parliament is not the final expression of sovereignty in a state, yet real sovereignty cannot be a mere figure head to Schmitt but must actually judge and rule when the exception calls for it.
} 
Schmitt, but that it reveals sovereignty, if it is there. If it is not there, the state of exception will end politics and do away with just authority.

So far, $21^{\text {st }}$ century states of emergency do not constitute a state of exception as Schmitt understood that state. For covid, or the 2008 global financial crisis, or the 9/11 terrorist attack, are not essentially political threats that might lead to the end of the polity as such, but external threats to the conditions of life. They are threats in the realm of zoe rather than bios, and they are threats of dominium - seen as the 'private' or internal sphere of the state's power - rather than threats of ius.

But the problem that Agamben and Milbank point out is, if there is no longer any real distinction between bios and zoe, and no longer any real distinction between dominium and ius, then we have an underlying absence of genuinely political authority, which is an underlying sovereignty vacuum. Is there, then, anything that makes justice distinct from power? Is, there, then, any real meaning to the notion of authority? If we have no God to appeal to; if we just make up law and governance; if the final reality about what a human being is is simply an animal reality, does a politics of the common good have any intrinsic dignity or is it all simply a sophisticated enterprise in propaganda that covers over the power-lust and self-interests of the already powerful? Is there anything that makes our laws reach towards a genuinely transcendent justice? Is there anything that makes the act of judgement sacred? Is there anything that makes the polis itself more or less good? Under the conditions of a fully secularized nature, there is a metaphysical crisis undergirding government and law which is foreign to the pre-19 $9^{\text {th }}$ century norms and customs in which we are still embedded. 
Under normal conditions, we do not concern ourselves with this underlying crisis, as the customs and norms of government and judgement carry the sense of justice and the common good, whatever our realpolitik and materialist theories may say. But when there is a threat to our way of life, then the crisis of sovereignty comes to the fore. It is then that the questions of whether government is just about power, and whether law is just about power, arise.

Returning to Schmitt, an external threat can parody the state of exception. But if an external threat uncovers the crisis of sovereignty itself, then the state of emergency can act as an opportunity to establish non-political dominium as a replacement for political ius. This, I think, is the real political danger that emergency biosecurity powers poses to us today.

\section{The State of Emergency, and the replacement of Politics with}

\section{Safety and Total Power}

Jacques Ellul points out that quantitative efficiency is increasingly replacing qualitative purpose as the guiding principle of life in our times. ${ }^{46}$ We are so wrapped up in the metrics of instrumental efficiency that we are becoming the tools of our tools. In a similar manner, Paul Virilio points out that in being committed to ever-fast, everimproving instrumentalities and metrics, we cannot stop to ask if we are going anywhere worth going. We are committed to speed itself. ${ }^{47}$ Shoshan Zuboff points out that we live in an age of surveillance capitalism where mega high-tech media companies monitor and prime

\footnotetext{
${ }^{46}$ Jacques Ellul, The Technological Society, New York: Vintage, 1964.

${ }^{47}$ Paul Virilio, The Great Accelerator, Cambridge: Polity, 2012.
} 
our every online move in order to make money out of us. ${ }^{48}$ Security as regards the mere conditions of personal wealth and freedom (dominium) and personal safety (zoe), are now the central 'political' concerns of our times. ${ }^{49}$ Our popularly elected leaders now largely present themselves to us as pragmatic and competent managers of monetary success and life-style security who will enable us to prosper in our consumer culture. Politics is reducing to economic and financial management. ${ }^{\circ 0}$ Political statesmen and stateswomen who have the moral and spiritual authority of elders, who have a wise and reflective vision of the meaning and purpose of distinctly human life, seem increasingly incompatible with contemporary political power. These trajectories have a profoundly corrosive civic impact on the bios and ius traditions of the moral and metaphysical purposes of the body politic, and equally, on the type of political leaders and political apparatchiks who are likely to succeed in such a civically diminished environment.

Quite possibly the contemporary moral and metaphysical barrenness of our political landscape is tied up with the manner in which modern naturalism does not allow any high or spiritual meaning to be real. We have become busy little cockroaches scurrying from one necessary feed and desirable breed to the next, all the while keeping a

\footnotetext{
${ }^{48}$ Shoshana Zuboff, The Age of Surveillance Capitalism, London: Profile, 2019.

${ }^{49}$ Paul Virilio, The Administration of Fear, Los Angeles: semiotext(e), 2012; Anthony Burke, Beyond Security, Ethics and Violence. War against the Other. London: Routledge, 2007.

${ }^{50}$ Michael Pusey, Economic Rationalism in Canberra. A Nation Building State changes its Mind. Cambridge: Cambridge University Press, 1991. Whether the economicization of politics leads or follows consumer culture is a complex question, but clearly both trends have been going in the same reductively materialistic direction from at least the 1980s. See Clive Hamilton and Richard Denniss, Affluenza, Sydney: Allen \& Unwin, 2005.
} 
watchful eye out to avoid baits and boots. As far as Classical Greek categories are concerned, we are no longer political beings. As far as theological categories are concerned, we are all 'material girls' now, and spirituality is just another marketed identity adventure. As far as Roman legal categories are concerned, our so-called political realist understanding of the nature of human life implies that the only real form of power is dominium, be it public or private. In this context, what keeps us governed?

When power has no high source of authority, government is only sustainable if it is convenient for the governed. If some eventuality arises that makes government inconvenient, then it is only control and force that sustains power. So when an emergency arises, greater control and more forceful power, and citizens being treated not as decision making political beings but as passive bodies, becomes increasingly necessary in order to establish non-political power and external physical force as the central means of governance.

After 9/11, ever stricter security measures and surveillance powers become normative for our government. They have not been wound back. After covid, it is increasingly mandatory to participate in public movement surveillance, just to do essential shopping (and everything else). Illegal private gatherings just to socialize are raided by the police with arrests made and heavy fines imposed, and the public is continually asked by our political leaders to notify the police of any lockdown infringement so that everyone "does the right thing". This is all for our zoe-defined safety, as if there are no other "right things" a person might want to do. 
As our naturalism allows for no higher purposes in life, zoe safety and the dominium of police power takes on the appearance of something approaching moral and metaphysical transcendence. The enhancement of the executive force of government and ever closer citizen surveillance is continuously ramped up. Should we find the next state of emergency is war in our region, complete civilian monitoring and control is already in place, and anyone considered in any way a threat to Australia's security - or anyone who is not a strict conformist to safe and suitably loyal modes of public behaviour - will be in the slammer in no time flat. Our governments now have the kind of surveillance and control power over the civic body that the Nazi regime could not dream of.

The appearance of sovereignty is being created by strong and sweeping executive responses to our present state of emergency, and similar responses to pervious apparent emergencies, such as 9/11 and 'invasions' from those asylum seekers who tried to violate our "sovereign boarders." But the very need to define acts of emergency executive dominium in the categories of sovereignty illustrates rather the absence than the presence of genuinely political and juridical authority. What we are actually being subjected to is a post-political parody of sovereignty exerted over the passive zoe of citizens, in which they have no political voice and make no political decisions. Government is increasingly the administration of unrestricted executive dominium..$^{51}$

\footnotetext{
${ }^{51}$ See Stan Grant, With the Falling of the Dusk, Sydney: HarperCollins, 2021. Grant points out that executive power is much better at actually achieving its desires outcomes in non-democratic non-liberal forms of government under increasingly globally insecure conditions. But actually, despite having the form of liberal democratic government, our government is increasingly bureaucratic, instrumental and non-responsive to the will of the people; it is trying to be non-political. We are
} 
This is not sovereignty. It is simply the administration of power by the state, supposedly for the only end we care about; the preservation of bare life. But this means that compliance with power gives one life, and, ultimately, non-compliance gives one death.

\section{The Crisis of Sovereignty, the treatment of Asylum Seekers, and} the Aboriginal desire for a Voice to Parliament

Perhaps the reduction of state power to the categories of executive dominium over the passive zoe of the physical bodies of the Australian people, is a dim historical echo of the disregard for the natural sovereignty of the Aboriginal people of this continent during its colonial conquest. Perhaps we now have some small intimation of what being treated like a mere object of power, without any respect for an intrinsic and transcendent understanding of prior sovereignty, means.

That the sovereignty of the Aboriginal Peoples was simply negated by colonial power meant that life itself would only be possible for the Aboriginal Peoples of this ancient continent under the terms of complete subjugation to British dominium. The alternative was death. Might banishes right and replaces Aboriginal sovereignty with the Crown. Power is transferred from Aboriginal sovereignty to the colonial governments by de facto conquest. What transcendent and intrinsic claim to self-rule and traditional ways Aboriginal Peoples had was simply overpowered by the colonial invaders. The colonial and then Australian refusal - to this day - to even acknowledge the

increasingly 'governed' in the categories of a CEO of a large and powerful corporation, though as citizens we don't seem to be shareholders, but we perhaps are the shares that get traded by the powerful who play above our heads. 
obvious fact that the ancient sovereignty of our First Peoples has never ceased to exist, shows one of two things: either a dishonest refusal to admit we have taken the Southern continent by violent conquest, or; a merely pragmatic determination to disallow any reasonable recognition of the natural right to self-determination that sovereignty entails in our own liberal democratic theories. Australia seems deaf to the obvious meaning of sovereignty when it comes to our First Peoples, such that it is questionable whether all the talk of Australian sovereignty over the past two decades is anything other than a propaganda stunt.

When an asylum seeker gets close to Australian shores and is taken to indefinite detention until they 'decide' to return to the place from which they have fled, we treat them as a threat to our safety and reduce them to a mere, though troublesome, zoe. They have no political rights. They have no human right to seek asylum. We treat them as subjects of Australian dominium, and they are the passive objects of the executive powers of our Immigration Minister. This is not about sovereignty; it is just about power.

Once we abandon the claims of any transcendently referenced ius upon us, once we find the concept of bios politikos indistinguishable from the concept of merely animal zoe, then we will treat others, and be treated ourselves, in sub-human ways. Under such conditions justice and political authority become merely the external trappings of centralized, technologically enhanced, amoral and non-political State dominium. Given the expansive powers of the modern State, the reduction of ius to dominium in the civic domain could signal the dystopian end of civic life as we have, till now, know it. We may be looking at the disintegration of the Greek idea of politics - of the bios politikos - itself. This would be a profoundly de-humanizing disaster. 
In this context the Uluru Statement from the Heart is as vitally important for non-Indigenous Australians as it is for our First Peoples. For unlike our Late Modern "bare life" and highly pragmatic political norms, many Indigenous Australians profoundly understand that "sovereignty is a spiritual notion." ${ }^{52}$ Indigenous Australians can enable us to re-learn that the very idea of sovereignty requires a firm commitment to the principles that might does not make right, that authority cannot be reduced to mere power, and that natural realities have inherently spiritual significances. The Uluru Statement arises from an appreciation of the reality of transcendent moral truths and a spiritual source of valid political authority. This reality stands above mere violently asserted sub-political dominium, and above a merely procedural democratic notion of parliamentary sovereignty. This is an appreciation that our pre-19 ${ }^{\text {th }}$ century English law heritage also has. We can recover our own roots if we will learn from Indigenous Australia.

Alas, it seems like our government does not presently grasp these matters. After a two year referendum council with extensive consultation, the Australian government of 2017 did not allowing the deeply significant bios-ius concerned Voice to Parliament proposal to be put to the Australian people in a referendum. This would have been 50 years since the 1967 referendum; it was the right time to act. Instead, we were required to vote on the zoe-dominium matter of legalizing gay

\footnotetext{
${ }^{52}$ Quoted from the "Uluru Statement from the Heart", 26 May 2017. As cited in Noel Pearson et al. , A Rightful Place. A Road Map to Recognition, Melbourne: Black Inc., 2017, 1.
} 
marriage. ${ }^{53}$ In 2017 the Turnbull government seemed to fear a loss of executive power that even the very modest and legislatively powerless Voice to Parliament proposed. The Turnbull government seemed to fear that a substantive recognition ${ }^{54}$ of the authority of Aboriginal leaders to sit in parliament to consult with the Australian government on matters that directly concerned Indigenous Australians, would be a threat to parliament's democratic legitimacy. This, I think, reveals just how serious our own crisis of sovereignty has become.

\section{Sovereignty and Biosecurity: Can we prevent ius from disap-} pearing into dominium?

As mentioned at the outset, in the context of a global pandemic there are compelling public safety reasons why emergency powers should be exercised by our governments. The argument I am putting forward has no objection to emergency powers as such. However, if we have a metaphysical crisis of political and juridical authority embedded in normal government and law, then executive enhancements of government powers almost inevitably enliven and entrench the reach and normativity of non-political State power. Under such

\footnotetext{
${ }^{53}$ In Greek categories, the political is acting outside of its domain in meddling in private matters, and the political domain itself is being ignored in refusing to address the unstarted business of recognizing prior Aboriginal sovereignty in our system of government.

${ }^{54} \mathrm{~A}$ range of arguments for meaningful constitutional recognition are powerfully presented in: Megan Davis \& Marcia Langton (eds.) It's Our Country, Melbourne: Melbourne University Press, 2016; Megan Davis \& George Williams, Everything you need to know about the Uluru Statement from the Heart, Sydney: NewSouth, 2021; Megan Davis \& George Williams, Everything you need to know about the Referendum to Recognise Indigenous Australians, Sydney: NewSouth, 2015.
} 
circumstances states of emergency tend to take on a life of their own whereby political government is increasingly replaced by surveillance invasive and forcefully policed State dominium.

Under the conditions of the modern crisis of sovereignty, biosecurity ${ }^{55}$ is in peril of reducing politics to the claims of the 'private' (that is, internally focused) dominium of executive State power over our public bare-life bodies (zoe). Agamben warns us about the political dangers of this situation in the clearest terms. ${ }^{56}$ But what alternative could we have?

We could recover the Western concept of sovereignty.

The first step here is to refuse the reduction of bios to zoe. This would mean treating modern totalizing naturalism with scepticism. ${ }^{57}$ Bios is meaningless if there is nothing transcendent and essential about the political form of human life. The spiritual traditions of the world have always maintained that this high dignity is incompatible with reductive animal naturalism, and equally that there is no such thing as mere nature in the modern sense. The very modern idea that nature has no spiritual meaning, is not overshadowed by the divine, and is not - at least in Christian categories - sacramentally significant as the work of the Creator, is actually very difficult to believe. The wonder and glories of nature do not naturally lend themselves to a spiritually evacuated theory of nature. However, harnessing the dark

\footnotetext{
${ }^{55}$ Ironically, in the terms of this paper, what we call biosecurity ('bios-security') is actually 'zoe-security'. Zoe-security as upheld by the dominium of the State can thus be a symptom of profound bios-insecurity.

${ }^{56}$ Giorgio Agamben, Where Are We Now? The Epidemic as Politics, London: Eris, 2021. ${ }^{57}$ For a brief argument in this direction see Paul Tyson, Seven Brief Lessons on Magic, Eugene USA; Cascade, 2019.
} 
energies of nature is very ancient. A violent and instinctive naturalism of competitive survivalism and callously self-interested instrumentalism does have strong resonance with the Sumero-Akkadian worship of violent power, ${ }^{58}$ and among Polynesian cannibal worshippers of violent power, but actually, those outlooks are far more spiritually framed than is modern reductive naturalism. And indeed, if humanity is intrinsically spiritual, then cults of death and the worship of power are more honest forms of naturalism than is a dull scientistic materialism. But even anti-theological naturalism is not anything like as non-theological or non-spiritual as it might like to believe. The Social Darwinian vision of nature has a genuinely dark spiritual energy that has strongly shaped commercial, colonial and international power from the $19^{\text {th }}$ century to the present, and its mythos is alive and well today in the West. A human understanding of nature is always - in one way or another - morally and theologically inflected. Seeking to be post-theological and amoral in our naturalism does not actually work.

Ius, in the Greco-Roman heritage of the West, is premised upon transcendent goodness and reasoned speech as more basic to a final account of true human reality than brute violent power. A commitment that far, without going theologically further, is adequate to draw back from the collapse of ius into dominium, to draw back from the collapse of bios into an amoral and sub-human zoe. The human dignity of law and government is then able to recover an intrinsic, morally defined and political notion of sovereignty.

${ }^{58}$ Paul Ricoeur, The Symbolism of Evil, Boston: Beacon Press, 1969, 175-198. 
Medieval Christendom is now decisively behind us, but naturalistic Late Modernity cannot retain a meaningful account of justice and authority. Our humanity is degraded without laws that are written and interpreted by the high aim of justice, and our governance becomes sub-political without a spiritual account of sovereign authority. To save our own political life from becoming a prison to the human spirit, then, we must start by recognizing the unextinguished spiritual sovereignty of First Peoples, and we must work towards meaningfully incorporating that sovereignty into our own system of government. If we accept that the Aboriginal claim to sovereignty is a spiritual and moral claim, then we may also re-discover that our own claim to sovereignty requires a genuinely spiritual and moral realist horizon of high meaning. Then Australian law and government will be able to recognize itself again as enlivened within the domain of bios and ius. Then we will be able to stop the anti-political and amoral drift towards treating all power as a brute naturalistic and instrumental dominium over the mute and passive zoe of the subjects of the State. 


\section{Works Cited}

Agamben, Giorgio. Homo Sacer. Stanford: Stanford University Press, 1998. Agamben, Giorgio. Where Are We Now? The Epidemic as Politics. London: Eris, 2021.

Aristotle, Metaphysics, trans. Hugh Tredennick \& G. Cyril Armstrong, Loeb Classics Library vol. 287, Cambridge MA: Harvard University Press, 1935 Augustine, City of God. London: Penguin, 1984.

Bartlett, Robert. The Natural and the Supernatural in the Middle Ages. Cambridge: Cambridge University Press, 2008.

Burke, Anthony. Beyond Security, Ethics and Violence. War against the Other. London: Routledge, 2007.

Burkert, Walter. Greek Religion. Oxford: Blackwell, 1985.

Burkert, Walter. Savage Energies. Chicago: University of Chicago Press, 2001.

Cahill, Thomas. How the Irish Saved Civilization. New York: Random House, 1996.

Das, Satyajit. Extreme Money. Masters of the Universe and the Cult of Risk, USA: FT Press, 2011.

Davis, Megan. \& George Williams, Everything you need to know about the Uluru Statement from the Heart. Sydney: NewSouth, 2021.

Davis, Megan. \& George Williams, Everything you need to know about the Referendum to Recognise Indigenous Australians. Sydney: NewSouth, 2015.

Davis, Megan. \& Marcia Langton (eds.) It's Our Country. Melbourne: Melbourne University Press, 2016.

Dodds, E.R. Pagan and Christian in an Age of Anxiety. Cambridge: Cambridge University Press, 1965.

Dodds, E.R. The Greeks and the Irrational. Chicago: University of Chicago Press, 1951.

Dupré, Louis. Passage to Modernity. New Haven: Yale University Press, 1993.

Ellul, Jacques. The Technological Society. New York: Vintage, 1964.

Freud, Sigmund. Civilization and its Discontents. London: Penguin, 2002.

Garrett, Brandon L. Too Big to Jail. How Prosecutors Compromised with Corporations, Cambridge MA: Harvard University Press, 2014. 
George, Susan. Shadow Sovereigns. How Global Corporations are Seizing Power, Cambridge: Polity, 2015.

Goetz, Stewart. \& Charles Taliaferro. Naturalism. Grand Rapids MI: Eerdmans, 2008.

Grant, Stan. With the Falling of the Dusk. Sydney: HarperCollins, 2021.

Hamilton, Clive \& Richard Denniss. Affluenza. Sydney: Allen \& Unwin, 2005.

Harrison, Peter. The Fall of Man and the Foundations of Science. Cambridge: Cambridge University Press, 2007.

Harrison, Peter. The Territories of Science and Religion. Chicago: The University of Chicago Press, 2015.

Henry, John. Knowledge is Power. London: Icon Books, 2002.

Hooykaas, Reijer. Religion and the Rise of Modern Science. Vancouver: Regent College Publishing, 2000.

Horton, Jonathan. "Limits of Legislation as a Source of Law: An Historical and Comparative Analysis." PhD (law) Thesis, The University of Edinburgh, 2015.

Jaeger, Werner. The Theology of the Early Greek Philosophers. Eugene OR:Wipf \& Stock, 2003.

Jones, Andrew Willard. "The Priority of Peace and the Problem of Power", Communio, 48, no. 2 (Summer 2021): 307-310.

Lewis, C.S. The Discarded Image. Cambridge: Cambridge University Press, 1964.

Lubac, Henri de. The Mystery of the Supernatural. New York: Herder \& Herder, 2018.

Machiavelli, Niccolò. The Prince. London: Penguin, 1961.

Mauss, Marcel. The Gift. London: Norton, 1990.

Milbank, John. Theology and Social Theory. $2^{\text {nd }}$ ed., Oxford: Blackwell, 2006.

Nietzsche, Friedrich. Beyond Good and Evil. New York: Dover, 1997.

Oliver, Simon. Creation: A Guide for the Perplexed. London: T\&T Clark, 2017.

Pearson, Noel. et al., A Rightful Place. A Road Map to Recognition. Melbourne: Black Inc., 2017.

Pieper, Josef. Guide to Thomas Aquinas. San Francisco, Ignatius Press 1991. 
Plato, Republic, trans. Paul Shorey, Lobe Classical Library, vol. 237, Cambridge MA: Harvard University Press, 1937.

Plato, Timaeus, trans. R.G. Bury, Lobe Classical Library, vol. 234, Cambridge MA: Harvard University Press, 1929.

Pliny the Elder, Natural History. London: Penguin, 1991.

Pusey, Michael. Economic Rationalism in Canberra. A Nation Building State changes its Mind. Cambridge: Cambridge University Press, 1991.

Ricoeur, Paul. The Symbolism of Evil. Boston: Beacon Press, 1969.

Ross, Chanon. Gifts Glittering and Poisoned. Eugene OR: Cascade, 2014.

Rowland, Tracey. Culture and the Thomist Tradition. London: Routledge, 2003.

Schmitt, Carl. Political Theology. Chicago: University of Chicago Press, 2005.

Schopenhauer, Arthur. The World as Will and Idea. London: Orion, 1995.

Shaxson, Nichols. Treasure Islands. Tax havens and the Men who Stole the World, London: Vintage, 2012.

Tharoor, Shashi. Inglorious Empire: What the British did to India, London: Penguin, 2018.

Thomas, Keith. Religion and the Decline of Magic. London: Penguin, 1971.

Tyson, Paul. Seven BriefLessons on Magic. Eugene OR: Cascade, 2019.

Varoufakis, Yanis. Adults in the Room. New York: Farrar, Straus and Giroux, 2018.

Varoufakis, Yanis. And the Weak Suffer What They Must? New York: Avalon, 2016.

Varoufakis, Yanis. et al., Is Capitalism Broken?, London: Oneworld Publication, 2020.

Varoufakis, Yanis. “Techno-Feudalism is Taking Over," Project Syndicate Op-ed, 28 June 2021, https://www.yanisvaroufakis.eu/2021/07/05/techno-feudalism-is-taking-over-project-syndicate-op-ed/

Virilio, Paul. The Administration of Fear. Los Angeles: semiotext(e), 2012.

Virilio, Paul. The Great Accelerator. Cambridge: Polity, 2012.

Weil, Simone. and Rachel Bespaloff. War and the Illiad. New York: New York Review of Books, 2005.

Zuboff, Shoshana. The Age of Surveillance Capitalism. London: Profile, 2019. 


\section{méta Working Papers}

The Centre for Postcapitalist Civilisation's working papers series, méta Working Papers, publishes peer-reviewed interdisciplinary research that explicitly or implicitly explores aspects of our liminal times, of our transition towards postcapitalist futures - be they dystopian or utopian, or anything in between. We are particularly interested in the exposure of academic works-in-progress to an audience of postcapitalismoriented thinkers.

It has been noted that it is easier to imagine the end of the world than the end of capitalism, invoking the need for serious reflection on the end of the existing order and a transition to a postcapitalist way of life. Yet the future of the world economy is but one of the aspects of postcapitalism. After all, capitalism itself might be prima facie an economic system, but it has evolved into a comprehensive political, cultural, anthropological and international order. Postcapitalism, however it might evolve, is not merely the modification of an economic system; it will prove to be a new political, cultural, anthropological, civilisational paradigm - a new era indeed. A dystopian one, a utopian one, or anything in between. And the turbulences of the gradual transition are to be witnessed by all. The oligarchic decline of liberal democracy engenders countless variations of authoritarian tendencies; the supply chain of tributes for the global minotaur are increasingly interrupted; novel desiderata for emancipation are articulated; the chasms between megacities and provinces nurture silent, cold civil wars; the emergence of a non-Anglophone, non-Atlantic, non-liberal, non-bipartisan state as the planet's largest economy is just around the corner, overturning a twocenturies-old order; the changes in global demography and geopolitics are vertiginous; climate change is threatening our very existence. Transformations of gigantic proportions radically reshape the world before our very eyes.

With social sciences and the humanities as our main launching pad, disciplines that are of interest to the méta Working Papers series include, but are not limited to, political economy, political science and international relations, history of ideas, sociology, law, religious studies, innovation and governance, area studies, and so on - provided that the research in question is of relevance to a lato sensu postcapitalist enquiry.

méta Working Papers welcomes solicited and unsolicited papers in English, Greek, or preferably both, on aspects of the nascent postcapitalist era and follows a single-blind peer review process. The Papers are on-line open-access publications under the Creative Commons CC BY-NC-ND license. An indicative word count would be around 3.500-7.000 words. References should follow the Chicago Style system, either notes+bibliography or author-date. Submissions must include an abstract. Authors must include a biographical note of 60-100 words. The editorial team maintains final discretion over publication of all content. Publication does not entail an endorsement of méta Working Papers' contents, which reflect the views only of the authors, and mé ta cannot be held responsible for any use which may be made of the information contained therein. Correspondence and submission:

postcapitalism.centre@gmail.com, cc'ing s.mitralexis@metacpc.org, with 'mźta Working Papers Submission' on the subject line. 